\title{
Beyond Exotic Wet Markets: COVID-19 Ecologies in the Global Meat-Processing Industry in Brazil
}

\author{
Jean Segata \\ http://orcid.org/0000-0002-2544-0745 \\ Federal University of Rio Grande do Sul, Brazil \\ Luiza Beck \\ https://orcid.org/0000-0002-6835-8370 \\ Federal University of Rio Grande do Sul, Brazil \\ Luísa Muccillo \\ https://orcid.org/0000-0001-7495-6564 \\ Federal University of Rio Grande do Sul, Brazil
}

\begin{abstract}
In this article we argue that the overvaluation of exotic narratives about wild animal consumption and wet markets conceals how the global agribusiness establishes unhealthy ecologies. Increasing infection rates from the new coronavirus registered among meat industry workers, their families, and the community, resulted in the suspension of several establishments in this sector in Brazil. If the meat processing industry cannot be considered entirely safe, why are risks to health, morality, and civility often represented by the unregulated practices of wet markets considered exotic? This paper shows that the global meat processing industry weaves a myriad of intimate encounters between humans, animals, highly toxic chemicals, organic waste, and precarious work relationships. They are unhealthy ecologies where coexistence, infection, risk, and death are always involved. We suggest a multispecies approach to analyse and respond to the COVID-19 pandemic; instead of the exaltation of contagion and the boundaries of contention, there needs to be an effort to establish integrated policies for the health and joint care of humans, animals, and environments.
\end{abstract}

Keywords: COVID-19, Global Meat-Processing Industry, Unhealthy Ecologies, Brazil, Multispecies Approach, Wet Markets

eTropic: electronic journal of studies in the tropics publishes new research from arts, humanities, social sciences and allied fields on the variety and interrelatedness of nature, culture, and society in the tropics. Published by James Cook University, a leading research institution on critical issues facing the world's Tropics. Free open access, Scopus Listed, Scimago Q2. Indexed in: Google Scholar, DOAJ, Crossref, Ulrich's, SHERPA/RoMEO, Pandora. ISSN 1448-2940. Creative Commons CC BY 4.0 free to download, save and reproduce. To cite, include: Author(s), Title, eTropic, volume, issue, year, pages and DOI: http://dx.doi.org/10.25120/etropic.20.1.2021.3794 
eTropic 20.1 (2021) Special Issue: Pandemic, Plague, Pestilence and the Tropics

$\mathrm{T}$

he relationship between meat consumption and the COVID-19 pandemic has written many stories. In this anthropological work, we will cross two of them. The first has to do with trying to explain the origin story of the new coronavirus arising from a bowl of bat soup in China. The second talks about illness in the production lines of meat-processing plants in southern Brazil. Focusing on this second story, our goal is to show how the overvaluation of exotic narratives about wild animal consumption obscures how the quotidian practices of capitalist global agribusiness shape harmful local relationships between humans, animals, and environments.

Firstly, we will show how narratives about the consumption of exotic meat in wet markets reinforce the Euro-American binary imaginary of nature's externality and opposition to society. It is this imaginary that underpins the idea that an unknown virus can suddenly emerge to threaten the social order. Secondly, we will put this type of narrative under tension by showing that favourable conditions for the emergence of new viruses that could instigate a pandemic occur amid the most mundane practices of daily life, such as those of the meat processing industry. In our analysis global agribusiness is a contemporary example of a complex machine of social and environmental destruction closely associated with situations that favour catastrophes like the one we have been experiencing with COVID-19. In particular, in Brazil, the industry modernises historical forms of predatory exploitation that characterised the Global North's actions in the colonisation of the tropics. Our criticism is that the strict international health protocols followed by this type of industry act to divert attention from countless related problems such as dangerous production lines, the precarious and exploitative work of humans and animals, and environmental destruction. We argue that biosecurity technologies do much more to protect global corporations than to promote the health of local human and animal populations and environments.

A pandemic is more than just a virus; it is a multispecies event. It involves humans, institutions, artefacts, and technologies, as well as animals, microorganisms, and environments. It also involves social injustices, precarious work, and environmental degradation in what Bruno Latour called "a profound mutation in our relationship with the world" (2020, p. 24). Following Kirksey and Helmreich (2010), the challenge assumed here is to make anthropology more sensitive to emerging modes of coexistence. The key is to allow animals, plants, insects, soils, and microbes to appear together with humans in the composition of the social. Including, in this case, animals, viruses, humans and the environment as social players with readable biographies and 
eTropic 20.1 (2021) Special Issue: Pandemic, Plague, Pestilence and the Tropics

as political protagonists involved in health and disease processes. ${ }^{1}$ Thus, we conclude the article by suggesting that instead of extolling contagion and the boundaries of contention between species, what we need are policies to integrate the care of humans, animals, and environments as a way of responding to critical events, such as the current COVID-19 pandemic.

\section{Performing Exotic Enemies}

In January 2020, when the outbreak of an unknown pneumonia species began to spread rapidly from Wuhan city in central China, an origin story emerged. The infection would have started, according to the narrative, with consumption of the meat of some wild animal sold in the city's wet markets - seafood, snakes, civets, pangolins. Exotic animals are usually under suspicion of allowing a new virus to "jump out of nature to humans" (spillover). Speculations gained many versions, but it was the image of "bat soup" that captured the world's imagination as the source of the pandemic. ${ }^{2}$

The "bat soup" origin synthesises a kind of narrative that has become increasingly common in the universe of biosecurity policies. Its plot insists on relating "exotic" (from the point of view of Global North countries) eating habits with the beginning of a new infection among humans. Stories like this had already been told in earlier epidemic episodes this century involving avian influenza, swine flu, and SARS (Keck, 2010, 2020; MacPhail, 2014; Mason, 2016; Porter, 2019; Segata, 2020). The idea is that certain non-human animals operate as natural reservoirs of pathogens such as viruses, bacteria, or protozoa. Through direct or indirect contact via bites, ingestion, fluid or waste exchanges, these pathogens can cross the species boundary and reach humans. Severe Acute Respiratory Syndrome (SARS-CoV-1), for example, which was responsible for about 800 deaths between 2002-2004 and at the time considered by the World Health Organization (WHO) to be the most severe infectious disease of the century with socioeconomic repercussions that paralysed the Asian continent, was initially characterised (like COVID-19) as a racially Chinese zoonosis transmitted from

\footnotetext{
${ }^{1}$ This work is part of the project "Covid-19 in Brazil: analysis and response to the social impacts of the pandemic among health professionals and the isolated population" of the Rede Covid-19 Humanidades MCTI, funded by the Ministry of Science, Technology and Innovations - MCTI (Convênio Ref.: 0464/20 FINEP/UFRGS). A Portuguese version of this work was previously published in Tessituras - revista de antropologia e arqueologia, vol. 8 (2), 2020. 2 See, for instance, "Coronavírus pode ter sido transmitido...", 2020. Traces of the virus were also found in sewage samples from several cities with dates before 2020 (Lodder \& Husman, 2020). Also, there were speculations that the virus had a laboratory origin - a theory now predominantly refuted, as indicated by the study in the journal Nature (Andersen et al., 2020). See also "How did Coronavirus..." 2020.
} 
eTropic 20.1 (2021) Special Issue: Pandemic, Plague, Pestilence and the Tropics

the consumption of some civet varieties, a so-called exotic animal which is found in the tropics and sold in wet markets. ${ }^{3}$

Processes involving contamination between humans and animals have complex ecologies and mechanics, but two explanatory trends stand out. The first, more classic, is that of cybernetic-epidemiological reasoning. It focuses on the different disease transmission stages between animals (enzootic-epizooty) and how this process progressed at population level until culminating in human infection (zoonosis). It is almost always used in situations where there is prior knowledge of the pathogen and its transmitters or vectors. Generally speaking, there are three different levels of circulation of a pathogen: it is found first among a given population of a specific animal species (enzooty); then, in the epizootic phase, it would begin to circulate and reproduce, generating events of more significant mortality (kill-offs); finally, in a "more linear than circular" way, the pathogen would reach humans, crossing the barrier between species and generating a zoonotic infection. Such is the case of cycles involving protozoa, sandflies, and dogs in the development of Leishmaniasis viruses, mosquitoes in Yellow Fever, or bacteria and rodents in Leptospirosis. This model was formative for explanatory theories and research methods on zoonoses.

The second explanation is called emergence (Keck \& Lynteris, 2018; Keck, 2020). This model's emphasis becomes the moment when new pathogens move from animals to humans jumping between species - the spillover. It is a random and inconvenient encounter that involves viruses, animals, environments, and humans. It can cause a dangerous combination of relational events capable of generating, for example, a viral mutation. The previous idea of a cycle, now gives way to a chain of events since a single encounter between person and animal is enough for the "leap" to reach humans. This type of model allows speculating on the notion of "patient zero" and the contaminant, which is increasingly incorporated into media, technical and popular discourses, and which has shaped many of the explanations about the origin of COVID-19. One of the social consequences of this model is the overvaluation of the idea that a multispecies encounter could trigger an epidemic. And it also sets the scene for a single species to be identified and converted into a "human enemy". It is in this human-animal interface that global health dynamics are reconfigured, since the

\footnotetext{
${ }^{3}$ Public opinion often accuses the civet of transmitting disease, but there is little debate about its use as a labor force to "produce" a variety of rare coffee, Kopi Luwak, extracted from its feces. In order to serve "Western refined flavor markets," these animals are forced to eat large quantities of coffee beans. According to Mason (2016, p. 46), civets were eventually "absolved" of their guilt in transmitting the virus since Chinese health authorities conjured that "humans would have infected small carnivores and not the other way around."
} 
eTropic 20.1 (2021) Special Issue: Pandemic, Plague, Pestilence and the Tropics

possibility of pandemic emergence starts to mark every interaction between people and animals - such as in the recent case of minks. ${ }^{4}$

The narrative of Wuhan's wet markets as the epicenter of the zoonotic leap of SarsCoV-2 follows the line of this emergence model. However, based on the work of anthropologist Alex Nading (2013), we argue that such an approach can contribute to a certain obscuration of how the interface between humans and animals works, and how multispecies contact and intimacy with non-human materialities (bacteria, fungi, and other microscopic life forms) builds the right environments for these diseases to evolve. Accordingly, it is necessary to think about more fluid and interactive borders between humans and animals, and not barriers and jumps (Nading, 2013). Nading suggests the idea of entanglement - where thinking with humans, animals, and pathogenic microorganisms collectively builds landscapes of coexistence where health and disease are just some of the relationships involved. Thinking through COVID-19 challenges essentialist conceptions regarding contagion at both a theoretical-discursive-epidemiological level and at the level of the materiality of viruses, which, the novel coronavirus shows, thrive on discontinuities and contradictions - or grey and fluid zones - between humans, animals and environments (that they together build and live in).

\section{Intentional Invisibility of the Common Enemy}

The other narrative involving the pandemic and meat consumption seems less appealing than the explanatory sensibilities of the virus's origin (story). Nevertheless, the worsening spread of novel coronavirus within the global large-scale meat processing agribusiness, especially meat-packing companies and slaughterhouses, also tells a story. Unlike the exotic characterisations with which Chinese wet markets are usually described, these "modern spaces", obedient to strict sanitary protocols, quietly operate in the transformation of animals raised in a regime of confinement into various "essential protein" commodities (aka meat). ${ }^{5}$

\footnotetext{
${ }^{4}$ During the process of reviewing this article, a new "enemy of humans" emerged in Northern Europe. Minks, the animals that in the haute couture industry become "mink coats" have been accused of transmitting the new coronavirus. The slaughter of 17 million of them started in November 2020. See more in "Dinamarca sacrificará milhões de doninhas...", 2020.

${ }^{5}$ We refer here to animals raised in the modern industrial production regime. The modern form, as Perrota (2016) argues, is one that "deals with the productive structure institutionalized and regulated by the State, in addition to corresponding, in modern and industrial societies, to the model responsible for most of the production of this food product" (Perrota, 2016, p.73).
} 
eTropic 20.1 (2021) Special Issue: Pandemic, Plague, Pestilence and the Tropics

Recently, production plants from this giant industry have been associated with numerous outbreaks of COVID-19 contamination in countries like the United States, Germany, and Brazil. ${ }^{6}$ The high rates of infection recorded in this type of industry among workers, their families and communities, resulted in the suspension of several establishments in the sector. In the southern Brazil State of Rio Grande do Sul, where we have developed our study, there were 5,804 confirmed cases of COVID-19 among workers in the slaughterhouse sector in the first six months of the pandemic between March and September, 2020.

By May 11, 2020, five state slaughterhouses had been partially or totally closed. On this date, the state government in conjunction with the Ministry of Agriculture, created a task force to investigate the situation of these industries. The task force was in charge of regularising the situation of establishments "in extreme situations"; that is, with activities suspended by court order due to outbreaks of the virus among employees. In Passo Fundo, a city in the north of Rio Grande do Sul, the industry shutdown for 15 days, generating, in mid-May, a protest organised by employees and outsourced workers for the industry's reopening. According to an interview conducted by local radio, workers emphasised that all preventive safety measures required by the Public Ministry of Labor (MPT) had been put in place, and they feared for their jobs. According to one interviewee, more than nine thousand families depend directly or indirectly on the activities of the city's slaughterhouse (LOBO, 2020). At the time of the mobilisation, nineteen meat processing plants were closed in Rio Grande do Sul (and another six in the neighboring state of Santa Catarina). Rio Grande do Sul had almost 500 confirmed cases of the disease among workers in the sector. In addition, more than thirty civil inquiries and three public actions have been initiated in court alleging irregularities in these industries. ${ }^{7}$

At the Federal level, the mobilisation around meat processing and slaughtering industries concerning COVID-19 began to occur as early as the end of March 2020, shortly after the first most publicly recognised impacts of the pandemic in the country, and the beginning of attempts to establish social distancing and isolation. On March 31, the Public Ministry of Labor (MPT) issued a joint note with guidelines to industries, prescribing the immediate adoption of a series of measures (Brasil, 2020a). Among the main ones, we highlight those related to social distancing and social isolation (from

\footnotetext{
${ }^{6}$ In the USA, meat-packing companies and slaughterhouses were considered local centers for transmitting the virus and called "the weakest link in the food chain". See, for example, "The food chain's..." (2020). In Germany, more than 1000 confirmed cases of COVID-19 had been reported from a single slaughterhouse at Germany's largest meat-processing plant. See "Coronavirus...", 2020. In Brazil, the states of Santa Catarina and Rio Grande do Sul gained prominence due to the huge number of cases of COVID-19 among slaughterhouse workers. See, "Por que os frigoríficos...", 2020.

${ }^{7}$ See also "Segundo MPT...", 2020 and "Com casos de coronavírus...", 2020.
} 
eTropic 20.1 (2021) Special Issue: Pandemic, Plague, Pestilence and the Tropics

the minimum distance of $1.8 \mathrm{~m}$ between each employee, to suspensions of work contracts, flexible working hours, removal of employees belonging to risk groups, work from home office, and dismissals). The other recommendations involved the sanitisation of environments, the use of PPE (personal protective equipment), masks, ventilation of spaces, and supporting the cost of tests for workers suspected of having the virus. The note also recognised meat processing plants as conducive to the transmission of the coronavirus, both because of the virus's characteristics and because of the environmental working conditions (Brazil 2020b).

However, the fast publication of Brazil's ministry of labor joint note failed to prevent a series of meat-packing companies and slaughterhouses from becoming epicentres of the disease over the following months. In June 2020, the number of meat industry workers testing positive for the new coronavirus reached $32 \%$ of cases in Rio Grande do Sul $-1 / 3$ of the infected population in the State at that time - suggesting that work with meat accounted for a large share of the internalisation of the disease in the state. On the 3rd of that month, the bulletin relating to Epidemiological Week 22, organised by the State Health Surveillance Center of RS - CEVS (2020), included in their classification of outbreaks the nature of the establishment of the occurrence. Three different categories were added, with "Category 1" dedicated specifically to Industries intended to manufacture food products (dairy and refrigerated products) and the other two categories reserved for companies in general and long-term institutions such as nursing homes and penitentiaries. In previous bulletins, discrimination as to the industry sector of origin of the novel coronavirus outbreak was restricted to "companies" and "closed institutions". 8

In addition to the risks associated with COVID-19, as explained in the ministry of labor joint note, the slaughterhouse work environment was also identified as responsible for several other types of threats to its workers' health. The slaughter or meat industry in the country concentrates high levels of accidents, intoxications, chronic infectious/parasitic diseases, and higher rates of interpersonal violence and alcoholism. Among the most frequent diseases of these workers (in relation to those in other sectors) are cancers of the airways and lungs, infections such as tuberculosis,

\footnotetext{
${ }^{8}$ In addition to creating a specific category for slaughterhouses and dairy products in order to map outbreaks, another political movement called attention to the positioning of meat industry as an "essential service". This category, which defines which services should continue fully or partially during the pandemic, announced by both then President Donald Trump and the Ministry of Agriculture, Livestock and Supply of Brazil (MAPA) (Brasil, 2020a), added another element to the field of disputes that constitutes the present moment. In the executive order, the then President even mentioned that the meat production chain (beef, pork, and poultry) constitutes the United States' critical infrastructure and that the necessary mitigation measures have dramatically affected that infrastructure. See "Executive order...", 2020.
} 
eTropic 20.1 (2021) Special Issue: Pandemic, Plague, Pestilence and the Tropics

diarrhea, gastroenteritis and septicemias, in addition to cuts, lacerations, amputations, and repetitive strain injuries (Brasil, 2020c).

The meat industry is part of what is most widely described as agribusiness, and accounts for more than a quarter of Brazil's economy. In public opinion, this industry is commonly called "the locomotive of Brazil". This economic factor is expressed in the urgent call for agribusiness to continue "full steam ahead". However, in addition to economic reasoning, the category of meat processing as an "essential service" refers to older questions surrounding agribusiness in southern Brazil. They are constituted by a kind of identity bias (an imaginary that associates gaucho and barbecue) as well as a particular discourse on dietary regimes animated by evolutionary arguments. According to Sordi (2016), in his ethnographic research on the meat industry in the Rio Grande do Sul, a speaker at one of the International Meat Productive Chain Fair (FEICORTE) symposia stated: "we have evolved by eating meat". The speaker further promoted that "the brain has developed, and $70 \%$ of the brain is fat, we need fat [...] it was from the consumption of meat that man went through to dominate the food chain" (Sordi, 2016, p. 54).

In the context of the pandemic, this centrality of meat in the diet also appeared in the disapproval note prepared by Brazilian associations ${ }^{9}$ regarding the decision to ban production plants in the state's municipalities of Lajeado and Passo Fundo. In the note, it is suggested that the lack of meat on supermarket shelves could cause social chaos: "with the stoppage of food production, there is a risk of inflation and shortages. Closed units can mean the absence of products in supermarkets. Processes that promote a decrease in food supply may, in the future, lead to social chaos."10 This note resonates with Lapegna and Otero's (2016) criticism concerning transgenic (genetically modified) crops and the worldwide movement to increase the meat industry. According to their analysis, the promise of food democratisation in economically vulnerable countries is linked with the idea that with meat on the table life looks excellent and fair, despite the industry's long, unhealthy and precarious workloads. With this economic and cultural observance of meat, it is little wonder that even with the intense coronavirus transmissions recorded in meat-packing companies in several countries,

\footnotetext{
${ }_{9}^{9}$ Among the associations that signed the note were the Brazilian Animal Protein Association (ABPA), the Gaúcha Poultry Association (ASGAV), the Union of Poultry Products Industries in the State of Rio Grande do Sul (SIPARGS), the Union of Poultry Industries Pork Products of the State of Rio Grande do Sul (SIPS) and the Association of Pigs Breeders of Rio Grande do Sul (ACSURS).

${ }^{10}$ See "Nota de repúdio...", 2020.
} 
eTropic 20.1 (2021) Special Issue: Pandemic, Plague, Pestilence and the Tropics

pandemics such as this one from Sars-CoV-2, nevertheless do not raise speculation regarding an origin in the "leap" of a virus coming from intensive livestock production. ${ }^{11}$

Finally, another consequence of COVID-19 in the meat industry - experienced mainly by the American reality but threatening Brazilian companies - would be that of the mass slaughter of animals due to the closure of slaughterhouses. In the United States since April 8 2020, some of the largest meat processing companies (Tyson Foods, JBS, Smithfield Foods, among others) have been temporarily closed. Farmers who normally sold their livestock to processing plants suddenly had to deal with overcrowding in confined spaces due to a lack of buyers. As a result, the emotions of countless animal protectionists were shaken in a perverse movement of trying to sensitize them to the need to kill animals so that they suffered less. Some zootechnical interventions were adopted to reduce the space that the animals occupied in order to avoid mass slaughter - among them, increasing the temperature of the pig barns to cause discomfort and disinterest in food, and changing the formula of the feed so that it was less appetizing. However, "it is a domino effect," said one of the farmers interviewed by The New York Times in a May 14 report. With no better alternatives, the report stated, farmers had to look for ways to kill their animals: euthanasia, carbon dioxide channelled through ventilation, and gunfire. According to another farmer quoted in the report, "there are farmers who cannot finish their sentences when they talk about what they need to do. This will cause people to leave the farms. We will have suicides in rural America."12

\section{Biosecurity, Capitalism, and Intensive Farming Diseases}

Stories with meat have even more to reveal. Food preferences in China go beyond exotic imaginaries of civets, pangolins, or bat soup. The country is one of the largest

\footnotetext{
${ }^{11}$ An exception may be an alternative attempt to trace the origins of Sars-CoV-2 from a causal relationship that researchers developed from universities in the United Kingdom and Brazil (Fiebrig et al., 2020). The paper suggests a threefold relationship between bats, industrial pigs and humans, that moves from the Chinese wet markets hypothesis and reaches industrial farms. In the argument, these humid and warm pig breeding environments would attract hungry bats, and the low immunity of pigs raised at large scale would be the facilitator for the first jump. The digestive system of pigs is similar to that of humans, as well as the biochemistry of its glycoproteins lining the throat, bronchi, lungs, and intestine. Since mucosal tissue is the primary "carrier" of the virus, the hypothesis is that its evolution, from pigs to humans, could have been less cunning and more facilitated than the hypotheses involving other animals - pangolins and seafood, for example (Fiebrig et al., 2020). According to explanatory models of the jump, it turns out that while the encounter between an infected animal and an unsuspecting human being can trigger a deadly pandemic, a series of other encounters is necessary for the transmission and persistence of the virus to allow its expansion. However, Fiebrig et al.'s (2020) article seems to be a story that only transfers the tired models of zoonotic explanations to other contexts. It would be interesting to further investigate the theses of the article with new research, which could help us to rethink the explanation of pandemics in other lands.

${ }^{12}$ See "Meat plants closures...", 2020. Regarding care practices between producers and their animals, also check Law (2010).
} 
eTropic 20.1 (2021) Special Issue: Pandemic, Plague, Pestilence and the Tropics

importers of meat - chicken, pork, beef - produced in Brazil. The commercial volume is so robust that it represented more than a $1 / 4$ of beef production and more than half of the pork production in 2019. ${ }^{13}$ Despite the fact that large portions of China's meat is sourced from Brazil, because of the outbreak in Wuhan, Brazilian politicians felt at liberty to accuse China of the pandemic's origin. They demanded China take responsibility for COVID-19 and raised suspicions of a conspiracy. ${ }^{14}$ In the meantime, a few batches of chicken wings - imported to China from Brazil - were found to be infected with the coronavirus and became embroiled in xenophobic reactions and diplomatic malpractice, even as they revealed that there are more expansive toxic problems in these global meat markets. Amid disputes over the precise position of the virus - whether it was on the packaging or directly on the surface of the wings - the World Health Organization (WHO) published a note stating that the meat was safe for consumption. However, what the WHO did not comment on was the dizzying increase of COVID-19 contamination amongst workers in the meat sector, which added to the industry's already precarious and unhealthy conditions. ${ }^{15}$

Much has also been written about the integration of markets into the global economy and the transport of goods, as well as international travel, airplanes, schools and hospitals, as areas of possible contagion par excellence (Segata \& Mastrangelo, 2020). In a previous work, Bevilaqua (2013), for example, wrote about how species considered "invasive" participate in this transit between people and goods; nevertheless, the very definition of "invaders" almost always remains dependent on the intentional action of humans. Yet viruses - besides the image of indomitable entities and violators of the norm - depend on a series of conditions cultivated by the relations between laws, humans, transport, and environments. In Bevilaqua's words:

The analyses show that the growing variety of goods and means of transport increases the number of species transported and the routes for their transfer to new locations. While the more frequent movement of goods through a more significant number of countries increases the pace and

\footnotetext{
${ }^{13}$ See "Exportação de carne bovina...", 2020, and "Metade das exportações...", 2020.

${ }^{14}$ See, for example, the troubled relations between Brazil and China during the pandemic, beginning with the resumption of imports after what was supposed to be the end of the then Chinese epidemic of the new coronavirus, in March 2020: "China volta a importar carne do Brasil..." (2020), "Brasil dobra vendas..." (2020), and "China suspende importações...", 2020. However, in addition to meat, moods between countries changed with accusations by Brazilian politicians that China was responsible for the pandemic, as in the following cases: "Eduardo Bolsonaro..." (2020), and "Celso de Mello abre inquérito...", 2020.

15 "Authorities in Shenzen, China, detect frozen chicken wings from a refrigerator at the Aurora de Santa Catarina company (the third-largest company in Brazil in processing pork and chicken). [...] ABPA (Brazilian Animal Protein Association) says that the contamination of the packaging may have occurred during transport/export, and insists that there is no evidence that meat can transmit the virus ". See "Frango brasileiro..." (2020) and "Frango...", 2020.
} 
eTropic 20.1 (2021) Special Issue: Pandemic, Plague, Pestilence and the Tropics

variety of introductions, faster means of transport can multiply the chances of an organism surviving in transit (Bevilaqua, 2013, p. 111). ${ }^{16}$

There is a long list of other places and circumstances understood to be relevant to the transmission of SARS-CoV-2 in the context of the 2020 pandemic: going to the supermarket, the races, using public transportation, restaurants and bars, and workspaces such as offices and industries. Although the circulation of the virus stretches the borders of nation-states in the dispute for accountability and in the agendas of containment strategies, its expansion is incorporated into already standardised and assured records of humans, objects, goods, and animal circulations. Therefore, the path of the virus also draws socio-political geographies. And thus it is necessary to put under tension the biosafety narrative as conceived from the Global North countries. Although it is said to be indiscriminate and that it affects all humans regardless of their race, gender, or socioeconomic situation, those most affected by the coronavirus disease are usually exposed to the various vulnerabilities and inequalities of the social fabric. The unhealthy landscapes of meat processing plants provide a sample of these places of exposure responsible for the worsening of the pandemic.

Thus, despite the frequent exoticism in which the origin of a virus is told, it is in the most ordinary everyday life that their stories of contamination are written. The meat processing industry is an example of this. It weaves a myriad of intimate encounters between humans, short-lived animals, low resistance to disease, highly toxic chemical and organic waste, and relationships of precarious work and shared suffering between humans and animals. Coexistence and contagion, disease affection and risk, life and death are regularly involved in these environments. ${ }^{17}$

In his recent work, anthropologist Alex Blanchette (2020) describes the unequal loads of Black and Latin bodies amid the American pork industry's precarious ecologies. He highlights the role of racial capitalism which drives migrants to excessive degrees of

\footnotetext{
${ }^{16}$ It is not the focus here, but there are evident links between the virus and the indomitable mushrooms of Anna Tsing (2015). Both transgress limits, circumvent systems, and question borders - above all, the control and the human imagination of the exception itself (Segata, 2020). Nevertheless, in the present work, we are more concerned with investigating how the virus's survival depends on a series of concrete - and, many times, already existing - articulations, which evidence the "ordinary" character of the epidemic despite its uniqueness, than with just philosophical consequences. See also Heather Paxson's (2008) notion of microbiopolitics and how Pasteurian policies that help sustain biosafety discourses try to impose vertical models of relationships between humans, animals, microorganisms, and environments, which facilitate the implementation of global infrastructures of food agribusiness.

${ }^{17}$ In mind here we have the work of Haraway (2009) and how she repositioned the relationship between humans and animals in laboratories. In her argument, it is not a question of merely taking animals as objects of human exploitation. In addition to instrumental relationships, both humans and animals are exploited as labor force in research institutions and they share countless loads of suffering.
} 
eTropic 20.1 (2021) Special Issue: Pandemic, Plague, Pestilence and the Tropics

porous contact with potentially contaminating substances. These are silent processes that intersect and embody capitalism and the Anthropocene and their racial, class, and multispecies hierarchies. An example described in Blanchette's ethnography is illustrative. Ponds surrounding pig manure farms receive high loads of antibiotics and other substances not processed by the porcine digestive system. The intense sun of the United States' southern deserts causes the liquid part of this manure to evaporate, taking the residual chemical particles with it. With rainfall, they reach the human and other animal populations of these regions and settle directly into their bodies, crossing the skin's porous borders. The dry part of the manure turns into dust. It settles in the lungs of workers and neighbours of these corporations through their breathing. Blacks, Latin migrants, and pigs, are precarious workers exploited by agrifood capitalism. They share situations of intense exploitation and suffering. Humans need to deal with manure, offal, and production lines that involve very low temperatures and accidents with sharp objects. For their part, the pigs work for these corporations on full-time shifts -24 hours a day, seven days a week. Pigs do not rest, they need to eat the processed feed intensively in order to produce muscle and fat in the shortest possible time to be recognised as "profitable work partners."

Similarly in Brazil, many of the COVID-19 contaminated meatpackers are young Black men, primary migrants from Venezuela and Haiti, and Indigenous people working in extremely precarious conditions (Granada et al., 2021). This situation invites us to draw parallels with colonialism and its long heritage of exploitation, particularly in the tropics. In this regard, Brazil has a colonial relation with the meat industry. The State of Rio Grande do Sul, for example, was a powerful international center of the beef jerky industry in the 19th century based on slave labor. White narratives repeatedly denied this history. Nevertheless, numerous works based on archival research have revealed evidence that slavery was one of the cruelest in Brazil, since the wounds on the bodies of slaves, resulting from constant punishment, were exposed to working conditions involving salt used to dry meat. The giant pieces of meat the men carried also intensified the precarious working conditions (Gutierrez, 2001; Koosby, 2021). Additionally, this meat labour history reveals environmental degradation related to untreated waste - rivers of blood and guts and clouds of rot and stench - and its association with other contaminations such as Plague (Schwartsmann, 2010). Contaminated rats travelled on trains that transported the cattle and the beef jerky between Brazil, Uruguay, and Argentina. In short, in both the past and the present, exploitation, precarious and racialised work, environmental degradation and pandemics seem to be intensely associated with the meat-processing industry. 
eTropic 20.1 (2021) Special Issue: Pandemic, Plague, Pestilence and the Tropics

In contemporary Brazil, swine landscapes and their smelly ecologies, with waste contaminated water and environmental degradation, have multiplied in recent decades. Small farmers from the interior have been converted into "rural entrepreneurs" who outsource animal production to large, networked corporations. The emergence of genetic engineering and international health protocols are facilitators of this extractivist and neoliberalist meat agribusiness (Segata, 2020a). The massive industry outlines uneven geographies but we are pacified by the promise of feeding the people, especially with meat, at low cost.

Biosecurity technologies endorse this scheme. They were designed, beginning in the 1970s, as laboratory protocols involved in the growing arena of genetic engineering. However, they have become increasingly robust political containment systems that define and distribute risks and vulnerabilities from almost always militarised imaginative performances. Data mining systems, geolocation software, and DNA technologies are part of the recent apparatus that makes it possible to identify the presence of an "invisible enemy" quickly - decipher its genome, map its transmission mechanics, and its circulation routes. It is an algorithmic and molecular surveillance system that echoes the technocratic fantasies of ubiquity and real-time (Caduff, 2015; Lakoff, 2017; Segata, 2020a; 2020b). These technologies are able to show the nature and performance of the viruses - their genetic structures and mutations - and model contamination and death scenarios based on this information. Nevertheless, by focusing on the viruses themselves, these technologies are not sensitive enough to capture the lack of water with which to wash hands in most of Brazil's impoverished communities (Segata 2020c). They are also not calibrated to detect the crowded buses that the agroindustry charters to transport their workers in the interior of Rio Grande do Sul, nor to realise that the poor, Blacks, women, and Indigenous people are converted into "essential service" to maintain the so-called "new normal" of the elites and the white middle class. These are some of the countless materialities, practices, and discourses, that favor and enhance the performance of the virus. The virus is just one of the many components of the pandemic. And the complexity of the pandemic cannot be summed up by just by viruses.

The point is that an increasingly broad imaginary has shaped a global project to convert health into a security issue and into a single commodity in actuarial markets (Segata, 2020a). This change in biosafety scale and nature has often been brought about and justified by an elastic idea of globalisation. It is responsible for expanding the production and international trade of products of animal and vegetable origin, the circulation of people, and knowledge and techniques of microbiology. It is a scenario constructed from catastrophe speeches about terrorist cells infiltrating among 
eTropic 20.1 (2021) Special Issue: Pandemic, Plague, Pestilence and the Tropics

migrants and refugees, especially Blacks, the poor, Latin Americans, Arabs - or mutant superbugs resistant to antibiotics and deadly strains of a dormant virus that crosses oceans through someone who had a bowl of bat soup for dinner. Thus, different areas of interest, such as that of health and climate emergencies, food autonomy and terrorism, crossed paths in the sights of State actions for the surveillance and control of humans, animals, artefacts, and environments (Caduff, 2014; Segata, 2020a; 2020b). Biosecurity policies are emerging forms of governmentality that favour large corporations of agrifood capitalism and foreign policies of neoliberal states. Biosecurity erects ever more rigid borders between nations, cultures, and species; and in the voluntary lack of skills to develop a more inclusive multispecies politics, it creates spaces of war and separation, instead of encounters and sharing.

\section{Conclusions and Contagions}

As we have shown throughout this work, there is a chronic disproportion between humans and animals when we tell contagion stories. Zoonoses and vector diseases often suggest asymmetries based on the general idea that "nature and animals" are foreign types that threaten "human societies and lives". The framework's central axis still rests on large divisions - nature and culture, humans and animals, tormentor and victim, contaminant and contaminated. Based on these binary models zoonoses and vector diseases are usually treated as one directional - from animals to humans. And this in turn gives way to the emergence of biosafety beyond the limits of laboratory processes. Biosecurity becomes an increasingly robust form of containment policy, as if humans were always in the sights of an enemy and on the verge of an imminent war against other humans, animals, microorganisms, and environments. Yet these are environments that humans, animals and microorganism both produce and share (Segata, 2020). A multispecies ethnographic perspective - in this instance involving disease and health - has helped us to put under tension narratives that support the fantasy of human exception. Notions like entanglement have repositioned health and disease as complex interactive processes between humans, animals, microbes, and environments. Health and illness are not just a one-way victim-tormentor business. What comes on the scene are the always unexpected, situated, contingent, and never complete encounters - a co-production, a becoming (Nading, 2013; Keck \& Lynteris, 2018). In short, a different policy of coexistence with its forms of engagement and belonging.

In terms of how the COVID-19 pandemic and meat consumption have written stories, multispecies ethnographies allow us to introduce reflections on ways of living and 
eTropic 20.1 (2021) Special Issue: Pandemic, Plague, Pestilence and the Tropics

dying together. They help us to highlight the meat agroindustry and its situations of shared suffering between species, which continues to be stubbornly obliterated by exotic narratives. Thus, if meat-packing companies and slaughterhouses cannot be considered entirely safe for either their human workers or animals, it is evident that the overexposure of Chinese wet markets as being responsible for the emergence of the pandemic is only a way to divert attention from the responsibilities of the large scale meat industry. The evident precariousness of the presumed safety of food produced in industrial environments calls into question the narrative about the risks against health, morality, and civility represented by unregulated meat. ${ }^{18}$

Pandemics are critical events that devastate lives and projects. However, it is necessary to situate them. There are materialities, speeches, and particular practices that act on multiple vulnerabilities, risks, and forms of illness (Segata, 2020). The meat industry is just one of many manifestations of this profound catastrophe that crosses our lives with those of other species and environments. The current question is how to think about methods to deal with occupational health policy in a world of increasingly complex capitalist substances.

As Ailton Krenak (2020, p. 20) notes, everyone (in Brazil) well remembers "the campaign agro is tech, agro is pop, agro is everything. (So), this calamity that we are living on the planet today can present her account to agribusiness". And this 'account' needs serious scrutiny. Since 2005 the World Health Organization (WHO) has been instructing us to use nomenclatures of viruses and infections encoded with letters and numbers without the geographical identifications which were previously embedded in the terms Spanish Flu, Nile Fever, or Zika virus. The argument is to mitigate stigmatisation and persecution of populations such as in the "Chinese virus" for the case of COVID-19. However, philogeographers, such as Rob Wallace (2020) interested in understanding the geographical origin of certain virus strains - questions this measure. While recognising the stigmatising potential of geographically named viruses, the criticism of this practice suggests an attempt to disrupt epidemiological research to map the evolution and spread of pathogens in order to calm the moods of countries that benefit from large agribusiness corporations and that fund the WHO.

Geography cannot be reduced to a political-spatial demarcation. It involves studying the dynamics of occupation and appropriation of environments. There is robust

\footnotetext{
${ }^{18}$ According to Perrota (2020), until the beginning of the pandemic, the meat industry still enjoyed an individual status as more sanitary, controlled, and safe than the Chinese wet markets. Wet markets like Wuhan, for example, are typically described as dirty and contaminating environments where people eat wild animals, raised or captured inappropriately or cruelly, supporting "some arguments that surround the public's imagination and offer justifications for their rejection and persecution." (Perrota, 2020, p. 2).
} 
eTropic 20.1 (2021) Special Issue: Pandemic, Plague, Pestilence and the Tropics

evidence of pathogens' exponential appearance in rapidly changing geographies, such as those housing emerging conurbations, monoculture crops, and animal farms in confinement. For Wallace (2020), the geographical identification of the origin of a virus and its infections would be a way to hold governments, states, and corporations responsible for the emergence of the virus accountable. In his words:

A more nuanced taxonomy is preferable. Once the factories that originated the last virulent outbreaks have been identified, we can name the new strains according to their corporate origins: the Bernard Matthews strain, the Charoen Pokphand virus, the Tyson cluster [all food industry conglomerates, especially meat-based]. Whatever the nomenclature, the reputation will be tarnished, not by intolerance or injustice, but by the infamy of governments and companies that have endeavored to put many millions of people in danger (Wallace, 2020, p. 57).

Catastrophes like pandemics are not only enacted with viruses. If there are enemies, capitalism is the truest of them - and it is not invisible. Like COVID-19, capitalism is also syndemic (a synergistic epidemic). The difference is that capitalism is a type of long death that enters the body and operates in the flesh, its industry that of suffering and chronic exploitation. ${ }^{19}$ The point is that we "have to stop developing and start to get involved" (Krenak, 2020, p. 24). Therefore, we must question more sharply the role of neoliberalism in the cultivation and intensive creation of diseases. The multispecies resistance to global capitalism must involve subsidies for the elaboration of coexistence policies and joint care for humans, animals, and environments.

\footnotetext{
${ }^{19}$ Here we keep in mind the idea of "long illness", explored by Fleischer (2018) regarding "disease chronicization" policies as well as Singer \& Rylko-Bauer's (2021) syndemics as a framework for analysing COVID-19. 
eTropic 20.1 (2021) Special Issue: Pandemic, Plague, Pestilence and the Tropics

\section{References}

Andersen, K.G., Rambaut, A., Lipkin, W.I., Holmes, E.C., Gary, R.F. (2020). The proximal origin of SARS-CoV-2. Nature Medicine 26, 450-452

https://doi.org/10.1038/s41591-020-0820-9

Bevilaqua, C. (2014). Espécies invasoras e fronteiras nacionais: uma reflexão sobre limites do estado. Anthropológicas, 24, 103-123.

Blanchatte, A. (2020). Porkopolis: American animality, standardized life, and the factory farm. Durham: Duke University Press. https://doi.org/10.1515/9781478012047

Brasil. (2020a). Ministério Público do Trabalho, Coordenadoria Nacional de Defesa do Meio Ambiente do Trabalho (CODEMAT). Projeto Nacional de Adequação do Meio Ambiente do Trabalho em Frigoríficos. Recomendação às Indústrias de Abate e Processamento de Carnes, em todas as suas Plantas Frigoríficas. Brasília, 31 mar. https://www.conjur.com.br/dl/recomendacao-projeto-frigorifico.pdf

Brasil (2020b). Ministério da Agricultura, Pecuária e Abastecimento/Gabinete da Ministra. Portaria 116/20. Dispõe sobre os serviços, as atividades e os produtos considerados essenciais pelo Ministério da Agricultura, Pecuária e Abastecimento para o pleno funcionamento das cadeias produtivas de alimentos e bebidas, para assegurar o abastecimento e a segurança alimentar da população brasileira enquanto perdurar o estado de calamidade pública decorrente da pandemia da COVID-19. https://www.in.gov.br/en/web/dou/-/portaria-n-116-de-26-de-marco-de2020-250059467

Brasil. (2020c). Ministério da Saúde, Universidade Federal da Bahia. Programa Integrado em Saúde Ambiental e do Trabalhador. Boletim epidemiológico: Doenças Infecciosas e Parasitárias Relacionadas ao Trabalho, incluindo a COVID-19. http://renastonline.ensp.fiocruz.br/sites/default/files/arquivos/recursos/dip_boletim_2 020_finalvs04052020_1.pdf.

Brasil dobra vendas de carne bovina à China enquanto isolamento pelo coronavírus afeta outros mercados. (2020). Available at:

https://g1.globo.com/economia/agronegocios/noticia/2020/04/14/brasil-dobravendas-de-carne-bovina-a-china-enquanto-isolamento-pelo-coronavirus-afetaoutros-mercados.ghtml

Caduff, C. (2014). On the verge of death: visions of biological vulnerability. Annual Review of Anthropology, 43, 105-121. https://doi.org/10.1146/annurev-anthro-102313-030341

Caduff, C. (2015). The pandemic perhaps: dramatic events in a public culture of danger. University of California Press. https://doi.org/10.1525/9780520959767

Celso de Mello abre inquérito contra Weintraub por racismo contra chineses. (2020). Available at:

https://www.correiobraziliense.com.br/app/noticia/politica/2020/04/29/interna_politic a,849567/stf-abre-inquerito-contra-weintraub-por-racismo-contra-chineses.shtml

China suspende importações de 3 frigoríficos brasileiros, diz ministério. (2020). Available at https://g1.globo.com/economia/agronegocios/noticia/2020/06/29/china-suspendeimportacoes-de-3-produtores-de-carne-do-brasil-diz-ministerio.ghtml

China volta a importar carne do Brasil com força, e já impulsiona arroba. (2020). Available at: https://www.moneytimes.com.br/china-volta-a-importar-carne-do-brasil-comforca-e-ja-impulsiona-arrobal

Com casos de coronavírus, frigoríficos são interditados no RS e em SC. (2020). Available at: https://economia.uol.com.br/noticias/estadao-conteudo/2020/05/18/com-casosde-coronavirus-frigorificos-sao-interditados-no-rs-e-em-sc.htm? 
eTropic 20.1 (2021) Special Issue: Pandemic, Plague, Pestilence and the Tropics

Coronavirus: German slaughterhouse outbreak crosses 1,000. 2020. Available at: https://www.dw.com/en/coronavirus-german-slaughterhouse-outbreak-crosses1000/a-53883372

Coronavírus: a busca pelo paciente zero. (2020). Available at: https://veja.abril.com.br/saude/coronavirus-a-busca-pelo-paciente-zero/

Coronavírus pode ter sido transmitido por sopa de morcego e carne de cobra. (2020). Available at: https://veja.abril.com.br/saude/coronavirus-pode-ter-sido-transmitidopor-sopa-de-morcego-e-carne-de-cobra/

CEVS. (2020). Centro Estadual de Vigilância em Saúde do RS. Boletim epidemiológico COVID-2019, semana epidemiológica 22 de 2020. Porto Alegre, 3 Jun. Available at: https://coronavirus.rs.gov.br/upload/arquivos/202006/04134058-boletimepidemiologico-covid-19-coers-se-22.pdf

Dinamarca sacrificará milhões de doninhas por mutação de coronavírus que infectou humanos. (2020). Available at: https://www.istoedinheiro.com.br/dinamarcasacrificara-milhoes-de-doninhas-por-mutacao-de-coronavirus-que-infectouhumanos/

Eduardo Bolsonaro culpa China por coronavírus e gera crise diplomática. (2020). Available at: https://g1.globo.com/jornal-nacional/noticia/2020/03/19/eduardo-bolsonaroculpa-china-por-coronavirus-e-gera-crise-diplomatica.ghtml

Executive order on Delegating Authority Under the DPA with Respect to Food Supply Chain Resources During the National Emergency Caused by the Outbreak of COVID-19. (2020). Available at: https://www.whitehouse.gov/presidential-actions/executiveorder-delegating-authority-dpa-respect-food-supply-chain-resources-nationalemergency-caused-outbreak-covid-19/

Exportação de carne bovina em 2019 bate recorde em volume e faturamento, diz associação. (2020). Available at:

https://g1.globo.com/economia/agronegocios/noticia/2020/01/08/exportacao-decarne-bovina-em-2019-bate-recorde-em-volume-e-faturamento-dizassociacao.ghtml

Fleischer, S. (2018). Descontrolada: uma etnografia dos problemas de pressão. EdUFSCar.

Fiebrig, I. Mies Bombardi, L., \& Nepomuceno, P. (2020). Hypothesising on the emergence of SARS-CoV-2 through bats: Its relation to intensive pig-factory farming and the agroindustrial complex. Available at:

https://www.researchgate.net/publication/341525356_Hypothesising_on_the emerg ence_of_SARS-CoV-2_through_bats_Its_relation_to_intensive_pigfactory_farming_and_the_agro-industrial_complex/citation/download

Frango brasileiro exportado a China aparentemente contaminado pelo COVID. (2020). Available at: https://economia.uol.com.br/noticias/redacao/2020/08/13/fragocoronavirus.htm

Frango: OMS diz que não existem evidências de transmissão por alimentos. (2020). Available at: https://noticias.uol.com.br/colunas/jamil-chade/2020/08/13/frango-omsdiz-que-nao-existem-evidencias-de-transmissao-por-alimentos.htm

Frigoríficos concentram mais de $30 \%$ dos casos de Covid-19 no RS. (2020). Available at: https://g1.globo.com/rs/rio-grande-do-sul/noticia/2020/06/03/frigorificosconcentram-mais-de-30percent-dos-casos-de-covid-19-no-rs.ghtml

Governo do RS cria força-tarefa para analisar situação dos frigoríficos devido ao coronavírus. (2020). Available at: https://g1.globo.com/rs/rio-grande-dosul/noticia/2020/05/11/governo-do-rs-cria-forca-tarefa-para-analisar-situacao-dosfrigorificos-devido-ao-coronavirus.ghtml 
eTropic 20.1 (2021) Special Issue: Pandemic, Plague, Pestilence and the Tropics

Granada, D. et al. (2021). Saúde e migrações: a pandemia de Covid-19 e os trabalhadores imigrantes nos frigoríficos do Sul do Brasil. Horizontes Antropológicos, vol. 27, n. 59 (forthcoming).

Gutierrez, E. (2002). Negros, charqueadas e olarias: um estudo sobre o espaço pelotense. Pelotas, Editora Universitária/UFPEL.

Haraway, D. (2011). A partilha do sofrimento: relações instrumentais entre animais de laboratório e sua gente. Horizontes Antropológicos, 17 (35), 27-64. https://doi.org/10.1590/S0104-71832011000100002

How did Coronavirus start and where did it come from? Was it really Wuhan's animal market? (2020). Available at: https://www.theguardian.com/world/2020/apr/28/howdid-the-coronavirus-start-where-did-it-come-from-how-did-it-spread-humans-was-itreally-bats-pangolins-wuhan-animal-market

Keck, F. (2010). Un monde grippé. Paris: Flammarion.

Keck, F. (2020). Avian reservoirs: virus hunters \& birdwatchers in Chinese sentinel posts.

Duke University Press. https://doi.org/10.1515/9781478007555

Keck, F. \& Lynteris, C. (2018). Zoonosis: prospects and challenges for medical anthropology. Medicine Anthropology Theory, 5 (3), 1-14. https://doi.org/10.17157/mat.5.3.372

Kirksey, E., \& Helmreich, S. (2010). The emergence of multispecies ethnography. Cultural Anthropology, 25(4), 545-576. https://doi.org/10.1111/j.1548-1360.2010.01069.x

Koosby, M. (2021). Comunidades multiespecíficas contra a agroindústria de processamento de carne: a pandemia de Covid-19 como parte das catástrofes capitalistas. [Postdoctoral statement of research]. Programa de Pós-Graduação em Antropologia Social, Universidade Federal do Rio Grande do Sul.

Krenak, A. (2020). A vida não é útil. São Paulo: Companhia das Letras.

Lakoff, A. (2017). Unprepared: global health in a time of emergency. University of California Press. https://doi.org/10.1525/9780520968417

Lapegna, P., \& Otero, G. (2016). Cultivos transgénicos en América Latina: expropriación, valor negativo y Estado. Estudios Críticos del Desarollo, Ciudad de México, 6 (2), $19-43$.

Latour, B. (2020). Diante de Gaia: oito conferências sobre a natureza do Antropoceno. São Paulo: Ubu Editora; Rio de Janeiro: Ateliê de Humanidades.

Law, J. (2010). Care and killing: tensions in veterinary practice. In Mol, A., Moser, I. \& Pols, J. (Eds). Care in practice: on tinkering in clinics, homes and farms. Transcript, 7087. https://doi.org/10.14361/transcript.9783839414477.57

Lobo, T. (2020). O trabalho indecente e a pandemia: o caso JBS Aves em Passo Fundo. Tessituras, 8 (1), 70-78.

Lodder, W. \& Husman, A. (2020). SARS-CoV-2 in wastewater: potential health risk, but also data source. Correspondence, 5 (6), 533-534. https://doi.org/10.1016/S24681253(20)30087-X

Mason, K. (2016). Infectious change: reinventing Chinese public health after an epidemic. Stanford University Press. https://doi.org/10.1515/9780804798952

MacPhail, T. (2014). The viral network: a pathography of the H1N1 Influenza pandemic. Cornell University Press.

Meat plants closures mean pigs are gasses or shot instead. (2020). Available at: https://www.nytimes.com/2020/05/14/business/coronavirus-farmers-killingpigs.html?auth=login-facebook

Metade das exportações de carne suína foi para a China. (2020). Available at https://www.suinoculturaindustrial.com.br/imprensa/metade-das-exportacoes-decarne-suina-foi-para-a-china/20190807-112635-d730 
eTropic 20.1 (2021) Special Issue: Pandemic, Plague, Pestilence and the Tropics

Nading, A. (2013). Human, animals and health: from ecology to entanglement. Environment and Society: Advances in Research 4, 60-78.

https://doi.org/10.3167/ares.2013.040105

Nota de repúdio: ABPA, ASGAV, SIPARGS e ACSURS questionam interdições de plantas e ressaltam impactos para o País. (2020). Available at:

http://asgav.com.br/index.php/noticias-interna/nota-de-repudio-abpa-asgav-sipargssips-e-acsurs-questionam-interdicoes-de-plantas-e-ressaltam-impactos-para-o-pais1597

Paxson, H. (2008). Post-Pasteurian cultures: the microbiopolitics of raw- milk cheese in the United States. Cultural Anthropology, 23(1), 15-47. https://doi.org/10.1111/j.15481360.2008.00002.x

Perrota, A. (2020). Serpentes, morcegos, pangolins e 'mercados úmidos' chineses: Uma crítica da construção de vilões epidêmicos no combate à Covid-19. Dilemas Revista de Estudos de Conflito e Controle Social, Rio de Janeiro, 2020. Available at: http://ppgcs.ufrrj.br/wp-content/uploads/2020/04/PERROTA-Serpentesmorcegos-pangolinsFI.pdf

Perrota, A. (2016). Abate bovino e rede industrial: um estudo sobre a introdução e gestão racional e econômica das emoções dos animais. Revista Política \& Sociedade, 15 (33), 68-65.

Por que os frigoríficos são foco de disseminação do coronavírus. (2020). Available at: https://www.nexojornal.com.br/expresso/2020/05/15/Por-que-osfrigor\%C3\%ADficos-são-foco-de-disseminação-do-coronav\%C3\%ADrus

Porter, N. 2019. Viral Economies: bird flu experiemnts in Vietnan. Chicago University Press. https://doi.org/10.7208/chicago/9780226649139.001.0001

Primeira morte por covid-19 no Brasil aconteceu em janeiro, diz ministério... (2020). Available at: https://noticias.uol.com.br/colunas/reinaldoazevedo/2020/04/03/primeira-morte-por-covid-19-no-brasil-aconteceu-em-janeirodiz-ministerio.htm

Research excludes Wuhun seafood market as origin of SARS-CoV-2: CAS. (2020). Available at: http://www.china.org.cn/china/2020-02/23/content_75735781.htm

Schwartsmann, L. (2010). Aspectos da Peste Bubônica em Porto Alegre no início do século XX. In Guilhermano, L., et al. Páginas da História da Medicina. (pp. 101-109). EdiPUCRS.

Segata, J. (2020). Covid-19, biossegurança e antropologia. Horizontes Antropológicos, 26 (57), 275-313. https://doi.org/10.1590/s0104-71832020000200010

Segata, J. (2020b). Covid-19, crystal balls, and the epidemic imagination. American Anthropologist, Arlington, Public Anthropology Series. Available at: http://www.americananthropologist.org/2020/07/02/covid-19-crystal-balls-and-theepidemic-imagination/

Segata, J. (2020c). Covid-19: scales of pandemic, scales of anthropology. Dispatches from the pandemic. Somatosphere. Available at: http://somatosphere.net/2020/covid-19scales-of-pandemics-and-scales-of-anthropology.html/

Segata, J. \& Mastrangelo, A. (2020). As biosseguranças e suas antropologias. Horizontes Antropológicos, 26, (57), 7-25. https://doi.org/10.1590/s0104-71832020000200001

Segundo MPT, número de casos confirmados entre funcionários de frigorífico de Passo Fundo subiu para 48. (2020). Available at: https://rduirapuru.com.br/cidade/segundo-mpt-numero-de-casos-confirmados-entrefuncionarios-de-frigorifico-de-passo-fundo-subiu-para-48/ 
eTropic 20.1 (2021) Special Issue: Pandemic, Plague, Pestilence and the Tropics

Singer, M., \& Rylko-Bauer, B. (2021). The syndemics and structural violence of the Covid pandemic: anthropological insights on a crisis. Open Anthropology Research, 1, 732. https://doi.org/10.1515/opan-2020-0100

Sordi, C. (2016). De carcaças e máquinas de quatro estômagos: controvérsias sobre o consume e a produção de carne no Brasil. Editora da UFRGS.

The food chain's weakest link: laughterhouses. (2020). Available at: https://www.nytimes.com/2020/04/18/business/coronavirus-meatslaughterhouses.html

Tsing, A. (2015). Margens Indomáveis: cogumelos como espécies companheiras. Ilha Revista de Antropologia, 17 (1), 177-201. https://doi.org/10.5007/21758034.2015v17n1p177

Wallace, R. (2020). Pandemia e Agronegócio: doenças infecciosas, capitalismo e ciência. Editora Elefante.

\section{Acknowledgements}

This work results from research carried out by the Rede Covid-19 Humanidades MCTI project, based at the Federal University of Rio Grande do Sul (UFRGS). We are thankful to the Financier of Studies and Projects (FINEP) of the Brazilian Ministry of Science, Technology and Innovation for supporting this project (FINEP / UFRGS Agreement n. 0464/20).

Associate Professor Jean Segata is with the Department of Anthropology at the Federal University of Rio Grande do Sul (Brazil), where he is the director of the NEAAT Centre for Animal, Environmental and Technology Studies. Recently, he was Craig Cogut Visiting Professor for Latin American and Caribbean Studies at Brown University. His teaching and research experiences intersect anthropology of science \& technology, health, and human-animal-environmental relations. Currently is the PI of the Rede Covid-19 Humanidades MCTI project. Email: jeansegata@ufrgs.br

Luiza Beck has a BSc. in Social Sciences (UFRGS) and Gastronomy (UFCSPA). She is currently a Master's Degree student in Social Anthropology (UFRGS) and a researcher of the Rede Covid-19 Humanidades MCTI project. Email: luizabeck@gmail.com

Luísa Muccillo has a BSc. Social Sciences (UFRGS), and is a researcher in the Rede Covid-19 Humanidades MCTI project. Email: luisamuccillo@outlook.com 